\title{
Environmental Effect on Biodegradability of Plastic and Paper Bags
}

\author{
${ }^{1}$ Olaosebikan Oluwatosin O., ${ }^{1}$ Alo, Moses N., ${ }^{2}$ Ugah, Uchenna I. and \\ ${ }^{3}$ Olayemi Albert M. \\ ${ }^{I}$ Department of Biological Sciences, Faculty of Science and Technology, Federal University, Ndufu - Alike, Ikwo. \\ ${ }^{2}$ Department of Medical Biochemistry, Faculty of Basic Medical Sciences, Federal University, Ndufu - Alike, Ikwo \\ ${ }^{3}$ Department of Microbiology, Faculty of Science, University of Ilorin.
}

\begin{abstract}
Biodegradation refers to the chemical dissolution of materials by microorganisms or other biological means. Biodegradable materials are those that can be consumed by microorganisms whereas biodegradability of a material refers to the ability of that material to be decomposed by biological agents, especially bacteria. Plastics are synthetic or semi - synthetic long chain polymeric molecules that are moldable. They are made from inorganic and organic raw materials, such as carbon, silicon, hydrogen, nitrogen, oxygen and chloride. The basic materials used for making plastics are extracted from oil, coal and natural gas. Plastics are biodegraded aerobically in wild nature, anaerobically in sediments and landfills and partly aerobically and partly anaerobically in composts and soil. Carbon dioxide and water are produced during aerobic biodegradation and carbon-dioxide, water and methane are produced during anaerobic biodegradation. Polythene \& plastic has become a part of modern day living right from packaging to making toys and various other applications. The environmental effect on the biodegradability of polythene bags (yellow nylon and black nylon), newspaper and brown paper were assayed by exposing the materials to different environmental conditions such as direct sunlight, fresh water, salt water obtained from the ocean leaf pile and soil. The bacteria present on the materials were identified and their colony counts performed at the start of the study and after three months. Physicochemical parameters were also analysed. Bacteria isolated from the biodegrading materials include; Pseudomonas aeroginosa, Proteus vulgaris and Enterobacter aerogenes, Staphylococcus aureus and Bacillus subtilis, while the fungi isolated include Penicillum chrysogenum, Aspergillus niger, Aspergillus flavus, Rhizopus stolonifer and Neurospora sitophila. The bacteria were organised into biofilms. There was in an increase in the bacterial and fungal colony counts after three months indicating their involvement in the biodegradation of the materials studied. This study has shown that paper bags are more liable to degrade faster than plastic bags and that environmental factors like salt water which represents the sea condition and sun has more effect on the biodegradability process of the suspended materials. It is therefore recommended to use more of paper bags for shopping and packaging of goods.

Keywords: biodegradation, plastics, paper bags, biodegradability.
\end{abstract}

\section{Introduction}

Plastics are synthetic or semi - synthetic long chain polymeric molecules that are moldable (Scott, 1999). They are made from inorganic and organic raw materials, such as carbon, silicon, hydrogen, nitrogen, oxygen and chloride. The basic materials used for making plastics are extracted from oil, coal and natural gas (Seymour, 1989).

Biodegradation refers to the chemical dissolution of materials by microorganisms or other biological means. Biodegradable materials are those that can be consumed by microorganisms whereas biodegradability of a material refers to the ability of that material to be decomposed by biological agents, especially bacteria. Organic material can be degraded aerobically, or anaerobically (Olayan et al., 1996). With the excessive use of plastics and increasing pressure being placed on capacities available for plastic waste disposal, the need for biodegradable plastics and biodegradation of plastic wastes has assumed increasing importance in the last few years (Sabir, 2002).

Degradation is a process which involves the physical or chemical change in polymer as a result of environmental factors such as light, heat, chemical conditions or biological activity. The process of degradation induces changes in polymer properties resulting in bond scission, chemical transformation and formation of new functional groups (Pospisil and Nespurek, 1997). The degradation is usually either due to photo, thermal or biological activities.

Awareness of the waste problem and its impact on the environment has awakened new interest in the area of degradable polymers. The interest in environmental issues is growing and there are increasing demands to develop materials which do not burden the environment significantly (Mueller, 2006). 
Sensitivity of polymers to photo-degradation is related to the ability to absorb the harmful part of the tropospheric-solar radiation. This includes the UV-B terrestrial radiation $(\sim 295-315 \mathrm{~nm})$ and UV-A radiation $(\sim 315-400 \mathrm{~nm})$ responsible for the direct photo-degradation (photolysis, initiated photo-oxidation). Visible part of sunlight $(400-760 \mathrm{~nm})$ accelerates polymeric degradation by heating. Infrared radiation $(760-2500 \mathrm{~nm})$ accelerates thermal oxidation (Joel, 1995). Most plastics tend to absorb high-energy radiation in the ultraviolet portion of the spectrum, which activates their electrons to higher reactivity and causes oxidation, cleavage, and other degradation (Joel, 1995).

Thermal degradation of polymers is 'molecular deterioration as a result of overheating'. At high temperatures the components of the long chain backbone of the polymer can begin to separate (molecular scission) and react with one another to change the properties of the polymer. The chemical reactions involved in thermal degradation lead to physical and optical property changes relative to the initially specified properties. Thermal degradation generally involves changes to the molecular weight (and molecular weight distribution) of the polymer and typical property changes include; reduced ductility and embrittlement, chalking, colour changes, cracking and general reduction in most other desirable physical properties (Olayan et al., 1996).

Oxo-biodegradation process uses two methods to start the biodegradation. These methods are photo-degradation (Ultraviolet) and oxidation. The Ultraviolet degradation uses UV light to degrade the end product. The oxidation process uses time, and heat to break down the plastic. Both methods reduce the molecular weight of the plastic and allow it to biodegrade (Joel, 1995).

Plastics are biodegraded aerobically in wild nature, anaerobically in sediments and landfills and partly aerobically and partly anaerobically in composts and soil. Carbon dioxide and water are produced during aerobic biodegradation and carbon-dioxide, water and methane are produced during anaerobic biodegradation (Day and Neale, 2002). Generally, the breakdown of large polymers to carbon dioxide (mineralization) requires several different organisms, with one breaking down of the polymer into its constituent monomers, another is able to use the monomers and excreting simpler waste compounds as by- products and yet another is able to use the excreted wastes (Day and Neale, 2002).

In the past 10 years, several biodegradable plastics have been introduced into the market. However, none of them is efficiently biodegradable in landfills. For this reason, none of the products has gained widespread use. Hence, there is an urgent need to develop efficient microorganisms and their products to solve this global issue.

Polythene \& plastic has become a part of modern day living right from packaging to making toys and various other applications. Normally they are petroleum products where alkenes oxides are polymerized to form plastics such as polythene. Plastic is one of the few new chemical material which pose environmental problems. Some microorganism such as bacteria, fungi, and actinomycetes are involved in the degradation of both natural and synthetic plastics.

This study aimed at determining the environmental effects on biodegradability of plastic bags and newspapers.

\section{Method of exposure}

\section{Materials And Methods}

Three types of plastic bags were folded and secured on top of a net with wire or string. A wooden post was tied at each end of the net and placed into the ground, leaving the plastic bags exposed to the sun. The same process was done using one brown-paper bag and a page of newspaper. The step above was repeated by placing the same types of bags in the middle of a mulch pile and also in the middle of the leaf pile. The mulch-pile was thoroughly wet with water. Three types of plastic bags, one brown-paper bag, and one page of newspaper were placed into five separate containers of tap water. The same types of materials were also placed into separate containers of $15 \%$ (by volume) saltwater. All the materials were allowed to stay in their environments for three months following the method as described by Athina and Reinart, (2012). The changes that occurred to the plastic bags, paper bags, and newspapers in the different environments were recorded upon removal.

\section{Determination of Physicochemical Parameters}

Physicochemical parameters were determined following standard methods. Temperature and $\mathrm{pH}$ were determined assayed using a mercury in glass thermometer and a standardized $\mathrm{pH}$ meter respectively. Other parameters were determined following procedures described elsewhere. These include; Biochemical oxygen demand and total dissolved solids (APHA, 1981). Others include conductivity, dissolved oxygen, carbondioxide, alkalinity, turbidity and titratable acidity as described by Fawole and Osho (1998).

\section{Moisture content determination}

This method was used for materials placed in the soil and leaf pile. A clean crucible was dried in an oven for about 30 mins and cooled in a dessicator. The cooled crucible was weighed as $\mathrm{W} 1$, then $2 \mathrm{~g}$ of each sample was then introduced into the dried crucible and was weighed as W2 before drying. This was placed in an 
oven set at $800 \mathrm{C}$ for an interval of $2 \mathrm{hrs}$ and cooled in a dessicator and weighed as W3. This was carried out until constant weight was obtained (Fawole and Osho, 1998). The moisture content was calculated as follows: Weight of oven dry crucible $=\mathrm{W} 1$; Weight of oven dry crucible + Sample $=\mathrm{W} 2$; Weight of oven dry crucible + dried sample $=\mathrm{W} 3$; Total loss in weight $=\mathrm{W} 2-\mathrm{W} 3$

Weight of sample $=\mathrm{W} 2-\mathrm{W} \%$ Moisture content $=\mathrm{W} 2-\mathrm{W} 3 \times 100$

\section{Ash Content determination.}

$$
\text { W2-W1 }
$$

This was carried out on soil and leaf pile samples. A clean crucible was weighed as W1. $2 \mathrm{~g}$ of the sample was added into the clean dried crucible and weighed as W2. The crucible and its contents was then transferred into the murfle furnace set at $600^{\circ} \mathrm{C}$ for about 6 hours, the colour change shows that it was fully ashed. The crucible and its contents was removed from the furnace and placed inside a dessicator to cool, after cooling it was then weighed as W3. The ash content of each of the sample was calculated as follows: Weight of dried crucible $=\mathrm{W} 1$; Weight of dried crucible + sample $=\mathrm{W} 2$; Weight of dried crucible + sample after ashing $=$ W3; Weight of sample $=(\mathrm{W} 2-\mathrm{W} 1) \mathrm{g}$

$$
\begin{gathered}
\text { Weight of Ash }=\quad \mathrm{W} 3-\mathrm{W} 1 \quad \text { x } 100 \\
\mathrm{~W} 2-\mathrm{W} 1
\end{gathered}
$$

Bacteriological Analysis

The bacteriological analyses of the samples in their different environments were carried out in the Laboratory using standard methods. The environmental effects on their biodegradation were also analysed. Samples were inoculated into the following media; Nutrient agar, MacConkey agar (Lab M Limited, Topley house 52 Welsh Lane, Lancashire, UK), Eosine Methylene Blue agar and Thioglycolate broth (Oxoid Limited, Wade road, Basingstoke, Hampshire, UK), Sabouraud dextrose agar and Potato dextrose agar (Sigma - Aldrich Corp, St. Louis MO,USA). Samples were collected and inoculated on the first day of the study and on the after three months interval.

\section{Enumeration of Total Coliform Bacterial Count (TCC)}

The membrane filtration method (MF) was used to enumerate the total coliforms present in the known volume of water sample as described by APHA (1981). Sterile Millipore membrane filter of $0.45 \mu \mathrm{m}$ was used, the culture medium of choice was Eosin methylene blue agar (EMB) for samples inoculated using the membrane filter. Water samples were diluted serially upto $10^{-3}$ and $1 \mathrm{ml}$ of the final dilution was used to inoculate molten media using the pour plate technique of inoculation. The plates were incubated both aerobically and anaerobically for 24 hours and up to 48 hours and the isolated colonies were counted. Characterization of the isolates was done using colonial and biochemical characteristics.

\section{Statistical analysis}

The data obtained was subjected to descriptive statistics using mean and standard Error of mean, Also, Analysis of variance (ANOVA) test under completely randomized design (CRD) was carried out.

\section{Results}

\section{Physical changes observed over 3 months of exposure}

The effect of salt on the materials placed in the salt water were discovered to be more conspicuous than the materials placed in the fresh water due to the drastic effect of the reaction which took place between the salt and the material. It was observed that after the first week of exposure, materials began to soften off until the paper bags started to tear off and the plastics bags became transparent and tears at the slightest pull. The materials placed in the fresh water began to soften off as from the $4^{\text {th }}$ week of exposure and by the $12^{\text {th }}$ week; the plastic bags had thinned off while the news and brown papers had started to tear apart. The samples placed in the sun gave high changes due to the effect of the ultraviolet rays on the materials. The changes were seen to begin as from the $3^{\text {rd }}$ week of exposure in which the materials became dry and by the $5^{\text {th }}$ week, the materials had changed colours. At the $7^{\text {th }}$ week of exposure, the plastic bags placed in the sun had become thin while the papers became wrinkled which began to break off by the $12^{\text {th }}$ week.

Materials placed in the leaf pile were a bit slow to changes because the changes observed started from the $4^{\text {th }}$ week of exposure. By the $6^{\text {th }}$ to $8^{\text {th }}$ week, the materials had become dry and by the $10^{\text {th }}$ week of exposure, they began to break off at the slightest pull. The samples placed in the soil were able to degrade because of the activity of organisms present in the soil. At the $4^{\text {th }}$ to $9^{\text {th }}$ week, materials had soften up and by the $10^{\text {th }}$ to $12^{\text {th }}$ week of exposure, the news and brown paper had began to degrade and only pieces of the papers were found left while the plastic bags had thinned off and became transparent. 


\section{Values obtained from Physicochemical properties carried out on water samples}

The mean $\mathrm{pH}$ values obtained for different samples and months ranged from 6.100 to 6.82 (Table 1). The mean temperature of the water samples at different months ranged from $23.0^{\circ} \mathrm{C}$ to $29.3^{\circ} \mathrm{C}$ (Table 1 ). The mean value of dissolved oxygen content oscillated between $18.80 \mathrm{mg} / \mathrm{L}$ in black nylon and $24.76 \mathrm{mg} / \mathrm{L}$ in brown paper. The mean values of turbidity ranged from 0.001 to 0.185 . The mean value of alkalinity ranged from and 5.667 to 23.00 respectively. The mean values of titratable acidity ranged from 0.25 to 1.05 and the values of biochemical oxygen demand ranged from $4.53 \mathrm{mg} / \mathrm{L}$ in Brown paper (Fresh water) to $41.16 \mathrm{mg} / \mathrm{L}$ in Black nylon (Salt water) as reported in Table 2. The mean values of Carbon-dioxide also ranged from 11.00 to 21.667. It was observed that the highest conductivity values were recorded in the salt water samples with mean values ranging from 1.700 to 39.40 while the mean values carbon dioxide also ranged from 11.00 to 21.6. The highest TDS and turbidity were obtained from the salt water samples. This is as a result of the chemical reaction going on between the salt, water and the samples. The total dissolved solids (TDS) ranged from 0.002 to 0.204 the highest value of titratable acidity was also recorded in salt water samples which ranged from 0.081 to 1.050 .

The mean Samples placed in the sun, leaf pile and soil were examined for their moisture content, ash content and ph (figure 1). The values ranged from 14.846 (leaf pile) to 63.65 (Soil) for moisture content and 14.62 (leaf pile) to 65.04 in soil for ash content. The $\mathrm{pH}$ values ranged from 9.75 to 9.91 (figure 2).

\section{Bacterial isolates and population}

We observed an increase in the population of the organisms on the first day and after three months. The organisms were clustered and were organized into biofilms. A total of five bacterial species were isolated and identified. Two of them were gram-positive bacteria while the remaining three were gram-negative. The organisms are Staphylococcus aureus, Pseudomonas aeroginosa, Bacillus subtilis, Proteus vulgaris and Enterobacter aeroginosa. The mean total viable counts, total coliform counts and total fungi counts in different environments of exposure and samples are presented in table 3 . There were no faecal coliforms present in the water samples which denote that the water samples were well treated from the source. The mean total viable counts were generally high and varied along with samples and the environment of exposure. The mean total viable counts ranged from $1.0 \times 10^{1} \mathrm{cfu} / \mathrm{mL}$ (Fresh water; Yellow nylon) to $6.9 \times 10^{6} \mathrm{cfu} / \mathrm{mL}$ (Soil; Brown paper).

The mean total coliform counts ranged from $1.5 \times 10^{1} \mathrm{cfu} / \mathrm{mL}$ (Salt water; Brown paper) to $5.4 \mathrm{x}$ $10^{1} \mathrm{cfu} / \mathrm{mL}$ (Fresh water; Black nylon). The highest fungi counts were recorded in Salt water; News paper. The mean values of fungi counts ranged from $0.6 \times 10^{1} \mathrm{cfu} / \mathrm{mL}$ to $2.6 \times 10^{1} \mathrm{cfu} / \mathrm{ML}$.

TABLE 1: Mean Total of Physicochemical properties of water samples taken for 3 months of exposure to different environmental conditions.

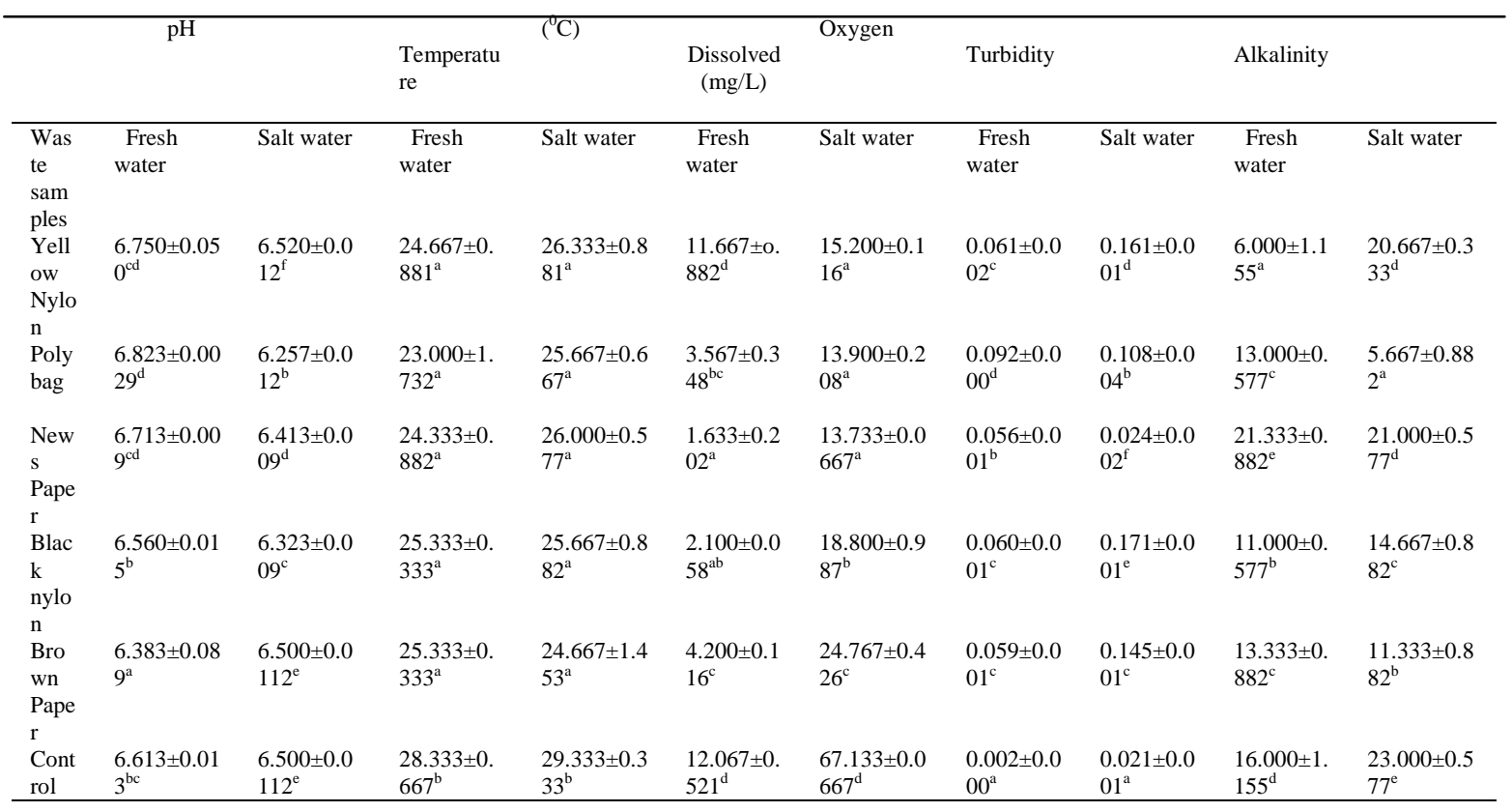

Values are presented as Mean \pm SEM

All groups are compared to each other at $\mathrm{P}<0.05$. Values with different superscripts along the same column are statistically different from each other. 
TABLE 2: Mean Total of Physicochemical properties of water samples taken for 3 months of exposure to different environmental conditions.

\begin{tabular}{|c|c|c|c|c|c|c|c|c|c|c|}
\hline & B.O.D & $(\mathrm{mg} / \mathrm{L})$ & Carbon- & dioxide & $\begin{array}{c}\text { Conductiv } \\
\text { ity }\end{array}$ & & T.D.S & $(\mathrm{mg} / \mathrm{L})$ & Titratable & acidity \\
\hline $\begin{array}{l}\text { Wast } \\
\mathrm{e} \\
\text { samp } \\
\text { les }\end{array}$ & $\begin{array}{l}\text { Fresh } \\
\text { water }\end{array}$ & Salt water & $\begin{array}{l}\text { Fresh } \\
\text { water }\end{array}$ & Salt water & $\begin{array}{l}\text { Fresh } \\
\text { water }\end{array}$ & Salt water & $\begin{array}{l}\text { Fresh } \\
\text { water }\end{array}$ & Salt water & $\begin{array}{l}\text { Fresh } \\
\text { water }\end{array}$ & Salt water \\
\hline $\begin{array}{l}\text { Yell } \\
\text { ow } \\
\text { Nylo }\end{array}$ & $\begin{array}{l}13.267 \pm 0.2 \\
67^{\mathrm{e}}\end{array}$ & $\begin{array}{l}27.767 \pm 0.1 \\
45^{\text {bc }}\end{array}$ & $\begin{array}{l}21.667 \pm 0.8 \\
82^{\mathrm{c}}\end{array}$ & $\begin{array}{l}14.667 \pm 0.3 \\
33^{\mathrm{c}}\end{array}$ & $\begin{array}{l}5.267 \pm 0.8 \\
82^{\mathrm{e}}\end{array}$ & $\begin{array}{l}39.000 \pm 0.0 \\
00^{\mathrm{d}}\end{array}$ & $\begin{array}{l}0.006 \pm 0.0 \\
02^{\mathrm{c}}\end{array}$ & $\begin{array}{l}0.163 \pm 0.0 \\
01^{\mathrm{d}}\end{array}$ & $\begin{array}{l}0.250 \pm 0.0 \\
29^{\mathrm{a}}\end{array}$ & $\begin{array}{l}0.433 \pm 0.3 \\
33^{\mathrm{b}}\end{array}$ \\
\hline $\begin{array}{l}\mathrm{n} \\
\text { Poly } \\
\text { bag }\end{array}$ & $\begin{array}{l}10.133 \pm 0.0 \\
66^{\mathrm{d}}\end{array}$ & $\begin{array}{l}27.033 \pm 0.3 \\
18^{\mathrm{b}}\end{array}$ & $\begin{array}{l}13.000 \pm 1.1 \\
55^{\mathrm{ab}}\end{array}$ & $\begin{array}{l}11.000 \pm 0.5 \\
77^{\mathrm{a}}\end{array}$ & $\begin{array}{l}3.633 \pm 0.0 \\
88^{\mathrm{d}}\end{array}$ & $\begin{array}{l}37.267^{\mathrm{b}} \pm 0.0 \\
88^{\mathrm{b}}\end{array}$ & $\begin{array}{l}0.012 \pm 0.0 \\
01^{\mathrm{a}}\end{array}$ & $\begin{array}{l}0.154 \pm 0.0 \\
01^{\mathrm{c}}\end{array}$ & $\begin{array}{l}0.350 \pm 0.0 \\
29^{\mathrm{a}}\end{array}$ & $\begin{array}{l}0.600 \pm 0.0 \\
57^{\mathrm{c}}\end{array}$ \\
\hline $\begin{array}{l}\text { New } \\
\text { s } \\
\text { Pape } \\
\text { r }\end{array}$ & $\begin{array}{l}9.100 \pm 0.05 \\
8^{c}\end{array}$ & $\begin{array}{l}26.000 \pm 0.0 \\
00^{\mathrm{a}}\end{array}$ & $\begin{array}{l}14.333 \pm 0.8 \\
82^{\mathrm{b}}\end{array}$ & $\begin{array}{l}16.000 \pm 0.5 \\
77^{\mathrm{d}}\end{array}$ & $\begin{array}{l}1.700 \pm 0.1 \\
16^{\mathrm{b}}\end{array}$ & $\begin{array}{l}39.067 \pm 0.0 \\
33^{\mathrm{d}}\end{array}$ & $\begin{array}{l}0.007 \pm 0.0 \\
03^{\mathrm{a}}\end{array}$ & $\begin{array}{l}0.164 \pm 0.0 \\
02^{\mathrm{d}}\end{array}$ & $\begin{array}{l}0.500 \pm 0.0 \\
57^{\mathrm{b}}\end{array}$ & $\begin{array}{l}1.050 \pm 0.0 \\
28^{\mathrm{e}}\end{array}$ \\
\hline $\begin{array}{l}\text { Blac } \\
\mathrm{k} \\
\text { nylo } \\
\mathrm{n}\end{array}$ & $\begin{array}{l}7.233 \pm 0.28 \\
5^{\mathrm{b}}\end{array}$ & $\begin{array}{l}41.167 \pm 0.0 \\
441^{\mathrm{e}}\end{array}$ & $\begin{array}{l}13.667 \pm 0.8 \\
82^{\mathrm{ab}}\end{array}$ & $\begin{array}{l}20.333 \pm 0.3 \\
33^{\mathrm{e}}\end{array}$ & $\begin{array}{l}6.133 \pm 0.0 \\
88^{\mathrm{c}}\end{array}$ & $\begin{array}{l}39.400 \pm 0.2 \\
00^{\mathrm{d}}\end{array}$ & $\begin{array}{l}0.001 \pm 0.0 \\
00^{\mathrm{a}}\end{array}$ & $\begin{array}{l}0.081 \pm 0.0 \\
00^{\mathrm{a}}\end{array}$ & $\begin{array}{l}0.767 \pm 0.0 \\
88^{\mathrm{c}}\end{array}$ & $\begin{array}{l}0.817 \pm 0.0 \\
44^{\mathrm{c}}\end{array}$ \\
\hline $\begin{array}{l}\text { Bro } \\
\text { wn } \\
\text { Pape }\end{array}$ & $\begin{array}{l}4.533 \pm 0.14 \\
5^{\mathrm{a}}\end{array}$ & $\begin{array}{l}34.200 \pm 0.1 \\
16^{\mathrm{d}}\end{array}$ & $\begin{array}{l}13.667 \pm 0.6 \\
67^{\mathrm{ab}}\end{array}$ & $\begin{array}{l}12.000 \pm 0.5 \\
78^{\mathrm{ab}}\end{array}$ & $\begin{array}{l}2.400 \pm 0.0 \\
58^{\mathrm{f}}\end{array}$ & $\begin{array}{l}38.100 \pm 0.0 . \\
058^{\mathrm{c}}\end{array}$ & $\begin{array}{l}0.013 \pm 0.0 \\
01^{\mathrm{a}}\end{array}$ & $\begin{array}{l}0.185 \pm 0.0 \\
01^{\mathrm{e}}\end{array}$ & $\begin{array}{l}0.757 \pm 0.0 \\
23^{\mathrm{c}}\end{array}$ & $\begin{array}{l}0.650 \pm 0.0 \\
29^{\mathrm{c}}\end{array}$ \\
\hline $\begin{array}{l}\mathrm{r} \\
\text { Cont } \\
\text { rol }\end{array}$ & $\begin{array}{l}17.033 \pm 0.3 \\
93^{f}\end{array}$ & $\begin{array}{l}27.967 \pm 0.2 \\
60^{\mathrm{c}}\end{array}$ & $\begin{array}{l}12.333 \pm 0.6 \\
67^{\mathrm{a}}\end{array}$ & $\begin{array}{l}12.000 \pm 0.5 \\
78^{\mathrm{ab}}\end{array}$ & $\begin{array}{l}0.210 \pm 0.0 \\
05^{\mathrm{a}}\end{array}$ & $\begin{array}{l}17.463 \pm 0.0 \\
09^{\mathrm{a}}\end{array}$ & $\begin{array}{l}0.110 \pm 0.0 \\
06^{\mathrm{b}}\end{array}$ & $\begin{array}{l}0.117 \pm 0.0 \\
03^{b}\end{array}$ & $\begin{array}{l}0.783 \pm 0.0 \\
09^{\mathrm{c}}\end{array}$ & $\begin{array}{l}0.293 \pm 0.0 \\
03^{\mathrm{a}}\end{array}$ \\
\hline
\end{tabular}

Values are presented as Mean \pm SEM. All groups are compared to each other at $\mathrm{P}<0.05$. Values with different superscripts along the same column are statistically different from each other.

TABLE 3: Percentage and ratio of Total viable, Total coliform and total fungi counts of the water samples for 3 months of exposure.

\begin{tabular}{|c|c|c|c|c|c|}
\hline $\begin{array}{l}\text { Environmental } \\
\text { conditions }\end{array}$ & Samples & $\begin{array}{l}\text { Total viable counts } \\
\mathrm{cfu} / 100 \mathrm{~mL}\end{array}$ & $\begin{array}{l}\text { Coliform counts } \\
\mathrm{cfu} / \mathrm{mL}\end{array}$ & $\begin{array}{l}\text { Feacal coliform } \\
\text { counts } \mathrm{cfu} / \mathrm{mL}\end{array}$ & $\begin{array}{c}\text { Fungi counts } \\
\mathrm{cfu} / \mathrm{mL}\end{array}$ \\
\hline \multirow[t]{5}{*}{ Fresh water } & Yellow Nylon & $0.10 \times 10^{2}$ & $0.23 \times 10^{2}$ & 0 & $0.6 \times 10^{1}$ \\
\hline & Poly-bag & $0.23 \times 10^{2}$ & $0.26 \times 10^{2}$ & 0 & $0.14 \times 10^{2}$ \\
\hline & News paper & $0.16 \times 10^{2}$ & $0.20 \times 10^{2}$ & 0 & $0.11 \times 10^{2}$ \\
\hline & Black Nylon & $0.26 \times 10^{2}$ & $0.54 \times 10^{2}$ & 0 & $0.18 \times 10^{2}$ \\
\hline & Brown paper & $0.18 \times 10^{2}$ & $0.24 \times 10^{2}$ & 0 & $0.12 \times 10^{2}$ \\
\hline \multirow[t]{5}{*}{ Salt water } & Black nylon & $0.30 \times 10^{2}$ & $0.26 \times 10^{2}$ & 0 & $0.22 \times 10^{2}$ \\
\hline & Brown paper & $0.10 \times 10^{2}$ & $0.15 \times 10^{2}$ & 0 & $0.8 \times 10^{1}$ \\
\hline & News paper & $0.35 \times 10^{2}$ & $0.40 \times 10^{2}$ & 0 & $0.26 \times 10^{2}$ \\
\hline & Poly-bag & $0.24 \times 10^{2}$ & $0.36 \times 10^{2}$ & 0 & $0.15 \times 10^{2}$ \\
\hline & Yellow nylon & $0.19 \times 10^{2}$ & $0.20 \times 10^{2}$ & 0 & $0.10 \times 10^{2}$ \\
\hline \multirow[t]{5}{*}{ Sun } & Yellow Nylon & $1.0 \times 10^{6}$ & - & - & - \\
\hline & Poly-bag & $1.6 \times 10^{6}$ & - & - & - \\
\hline & News paper & $1.3 \times 10^{6}$ & - & - & - \\
\hline & Black Nylon & $2.1 \times 10^{6}$ & - & - & - \\
\hline & Brown paper & $1.2 \times 10^{6}$ & - & - & - \\
\hline \multirow[t]{4}{*}{ Soil } & Yellow Nylon & $4.0 \times 10^{6}$ & - & - & - \\
\hline & Poly-bag & $3.5 \times 10^{6}$ & - & - & - \\
\hline & News paper & $6.4 \times 10^{6}$ & - & - & - \\
\hline & Black Nylon & $6.2 \times 10^{6}$ & - & - & - \\
\hline \multirow[t]{2}{*}{ Leaf pile } & Brown paper & $6.9 \times 10^{6}$ & - & - & - \\
\hline & All samples & $1.4 \times 10^{6}$ & - & - & - \\
\hline
\end{tabular}


Figure 1: Physicochemical parameters carried out on soil samples.

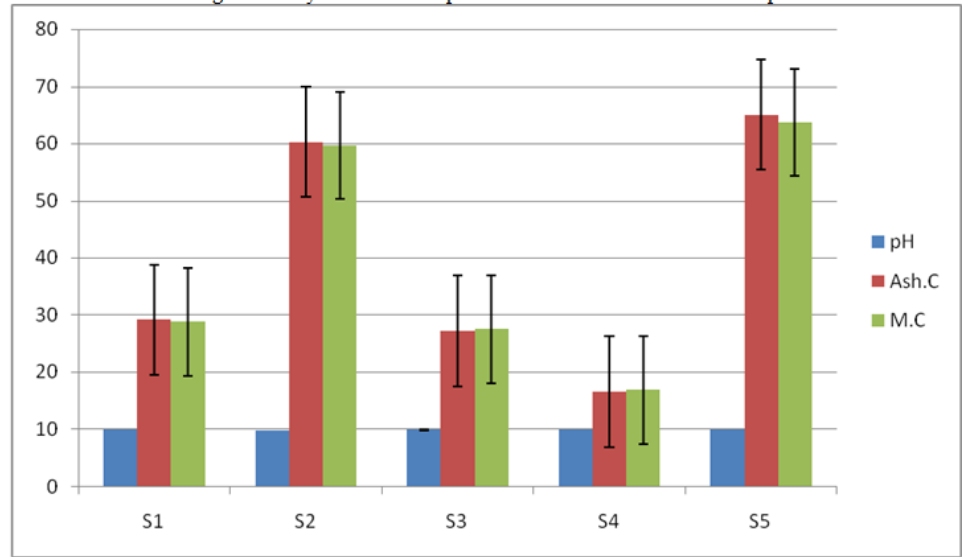

Key: Ash.C = Ash content

M.C.= Moisture content

$\mathrm{S} 1$ = Poly-bag

S2 = Yellow nylon

S3 = Black nylon S5 = Brown paper

S4 = News paper

Figure 2: $\mathrm{pH}$ carried out on selected materials exposed to the sun for 12 months

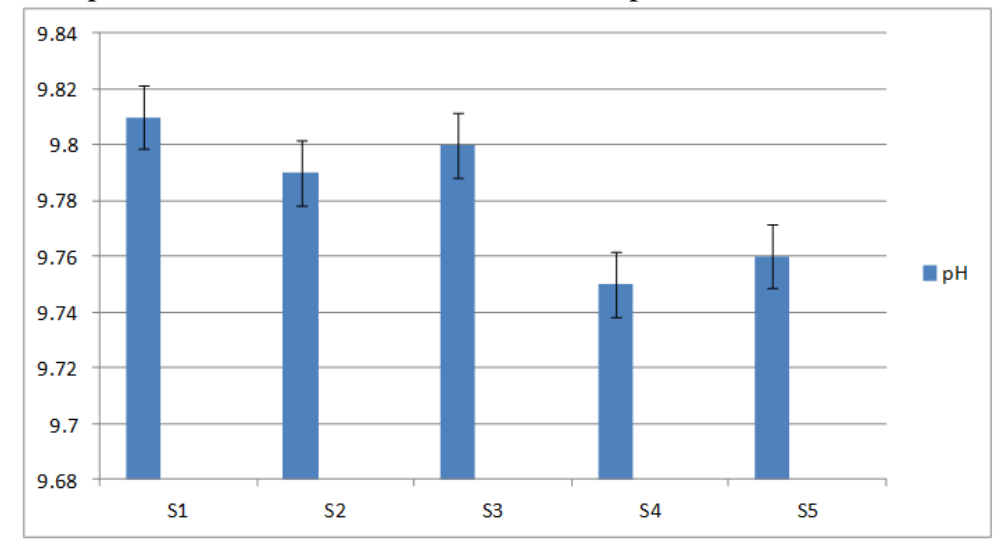

Keys:

$$
\begin{aligned}
& \text { S1 = Poly-bag } \\
& \text { S2 = Yellow nylon } \\
& \text { S3 = Black nylon } \\
& \text { S4 = News paper } \\
& \text { S5 = Brown paper }
\end{aligned}
$$

\section{Discussion}

The selected plastic bags and papers placed in the salt water began to show physical changes after the second week of exposure. The materials became soft and the softness increased in the $5^{\text {th }}$ to $7^{\text {th }}$ week of exposure thereby giving way to thinning out of the plastic bags in the $8^{\text {th }}$ and $9^{\text {th }}$ week of exposure as a result of the reaction going on between the salt, water and the materials. Transparency and tearing were seen to occur in the $10^{\text {th }}$ to $12^{\text {th }}$ week of exposure of the plastic materials to salt water as a result of increase in time of the exposure in agreement with the report of Julian and Jason (2012) who also discovered that after 66 days of plastic strips immersed, strips showed physical changes such as thinning in some portions and discolouration. In the $8^{\text {th }}$ and $9^{\text {th }}$ week of exposure of papers to this environment, the material had become soft and began to tear by itself as a result of the salt-water reaction, this had also been reported by Jennings (2012).

The first three weeks of exposure of the selected plastic bags and papers to fresh water showed no physical changes unlike the salt water environment. The materials became soft in the $4^{\text {th }}$ to $5^{\text {th }}$ week of exposure and the softness continued to the $6^{\text {th }}$ and $7^{\text {th }}$ weeks of exposure. The physical effect became more conspicuous as the weeks increased, and at the $8^{\text {th }}$ to $10^{\text {th }}$ week the news paper and the brown paper had become soft and by the $11^{\text {th }}$ to $12^{\text {th }}$ week the papers had started to tear at a pull still in correlation with the report of Jennings ( 2012). The plastic bags had begun to thin off at $8^{\text {th }}$ week of exposure also in agreement with the findings of Julian and Jason (2012). The physical changes observed in this environment were slow compared to salt water environment. This observed difference can be attributed to the salt present in one of the environments. 
The $1^{\text {st }}$ to $2^{\text {nd }}$ week of exposure of the selected waste materials to the sun gave no physical changes. As from the $3^{\text {rd }}$ week of exposure, the selected plastic bags and paper became dry as a result of the effect of the ultraviolet rays as explained by Alian et al. (2004). The plastic bags began to fade in colour as from the $5^{\text {th }}$ week of exposure so much that at the $11^{\text {th }}$ to $12^{\text {th }}$ week, the plastic bags had thinned off and started to tear at a pull in correlation with Day and Neale, (2002), who reported that Sensitivity of polymers to photo-degradation is related to the ability to absorb the harmful part of the tropospheric solar radiation. This includes the UV-B terrestrial radiation $(\sim 295-315 \mathrm{~nm})$ and UV-A radiation $(\sim 315-400 \mathrm{~nm})$ responsible for the direct photodegradation (photolysis, initiated photooxidation). Visible part of sunlight (400-760 nm) accelerates polymeric degradation by heating. Infrared radiation $(760-2500 \mathrm{~nm})$ accelerates thermal oxidation. Most plastics tend to absorb high-energy radiation in the ultraviolet portion of the spectrum, which activates their electrons to higher reactivity and causes oxidation, cleavage, and other degradation Sensitivity of polymers to photo-degradation is related to the ability to absorb the harmful part of the tropospheric solar radiation. When exposed to sunshine, polyethylene's polymer chains become brittle and crack, eventually turning what was a plastic bag into microscopic synthetic granules. The physical changes observed in the $5^{\text {th }}$ week are in contrary to the observation of Athnia and Reinart, (2012) due to the difference in climatic condition in both studies. The Paper bags had changed colour by the $5^{\text {th }}$ week of exposure in so much that by the $7^{\text {th }}-10^{\text {th }}$ week they had become wrinkled, crumpsy and appeared burnt and by the $11^{\text {th }}$ week, the papers had started to break off at a touch as a result of the effect of the ultraviolet rays from the sun as reported by Jennings, (2012) that light naturally degrades paper in a process called photolytic degradation to which news prints is the most vulnerable.

The leaf pile environment showed a very slow impact in biodegradation. For the first three weeks of exposure of the selected plastic bags and paper to this environment, no physical changes were observed not until $4^{\text {th }}$ to $6^{\text {th }}$ week when the materials started to dry off and by the $7^{\text {th }}$ week, they had become dried and wrinkled. On the $10^{\text {th }}$ week, the plastic bags became wrinkled and thinned off and had appearance of holes as a result of the activities of the microorganisms present in the environment. This in correlation with Julian and Jason, (2012). The paper bags became dried by the $10^{\text {th }}$ week of exposure which is also in agreement with work of Jennings, (2012) who discovered that paper of any kind is more likely to survive in dry, cool environments.

The selected materials placed in the soil showed no physical changes in the $1^{\text {st }}$ to $3^{\text {rd }}$ week of exposure, but by the $4^{\text {th }}$ week, the materials had become moist and soft and by the $7^{\text {th }}$ week, the plastic bags had become softer and the paper bags began to tear apart. On the $10^{\text {th }}-12^{\text {th }}$ week, the plastic bags had become soft and thin/transparent and the papers had degraded leaving little pieces left. This is in correlation with the work of Jennings, (2012) who reported that warmth and humidity hastens the degradation of paper. The result is also explained in the work of Shah et al. (2011), that Some modern bags are made of vegetable-based bioplastics, which can decay organically and prevent a build-up of toxic plastic bags in landfills and the natural environment.

The $\mathrm{pH}$ of the samples tends to increase with time when exposed to different environmental conditions. The $\mathrm{pH}$ in the salt water and tap water tends to neutral. Though, the materials placed in the salt water samples degraded faster compared to its counterparts placed in the tap water.

The high $\mathrm{pH}$ in the salt and fresh water samples tends to be high in order to favour the growth of the microorganisms used in biodegradation of the materials in agreement with the work of leady and Colwell, (1990).

Aerobic bacteria use oxygen as an electron acceptor, and break down organic chemicals into smaller organic compounds, often producing $\mathrm{CO}_{2}$ and water as the final product which denotes high oxygen demand in salt water due the effect of the salt added while low in fresh water because the dissolved oxygen have been used by the organisms for biochemical processes which is also responsible for the slow response of the materials placed in this environment to changes as reported by Priyanka et al. (2011), that in anaerobic condition whether a material is biodegradable makes little difference: biodegradable matter usually does not decay, because of the lack of oxygen required by the microorganisms. This observation is also in correlation with the work of Xunchi and Zhao, (2005) who reported that when the re-aeration rate is low, the dissolved oxygen cannot be supplied in time so that the dissolved oxygen concentration decreases gradually, resulting in the rate of biodegradation decreasing. Barlaz et al. (1989) also discovered that when Oxygen is available, aerobic microorganisms are mostly responsible for destruction of complex materials, with microbial biomass, Carbon-dioxide, and water as the final products. When dissolved oxygen concentration decreases gradually, resulting in the rate of biodegradation decreasing as reported by Xunchi and Zhao, (2005).

The biochemical oxygen demand values were extremely high in salt water as a result of the chemical reactions which took place between the water, salt and the material. The increase in value in this environment is also due to the biochemical reactions which took place between the microorganisms in correlation with the work of Priyanka, (2011) who observed that some anaerobic bacteria use nitrate, sulfate, iron, manganese, and carbon dioxide as their electron acceptors, and break down organic chemicals into smaller compounds due to the compounds secreted extra-cellularly by the microbes that may break the complex molecular structure of plastics. 
When the organic compound concentration is higher, the re-aeration rate not only affects the biodegradation rate, but also results in its change. The free carbon-dioxide present in the salt water sample are been trapped down by the salt added thereby giving high amount of $\mathrm{CO} 2$ present compared to the tap water samples whose free $\mathrm{CO} 2$ have given off. Conductivity is the ability of water to conduct electric current. $\mathrm{NaCl}$ enhances the conductivity potential of a water sample. This is because, the salt ionises with water which becomes ionised water. This also fosters degradation process in a way. Due to the effect of salt on the waste samples placed in the salt water which gradually degrades the sample leading to high amount of dispersed materials, the total dissolved solids also increases which is also in agreement with the work of Alien (2004).

Bacteria isolated from the biodegrading materials include; Pseudomonas aeroginosa, Proteus vulgaris and Enterobacter aerogenes, Staphylococcus aureus and Bacillus subtilis, while the fungi isolated include Penicillum chrysogenum, Aspergillus niger, Aspergillus flavus, Rhizopus stolonifer and Neurospora sitophila. Other studies have also isolated these organisms in degrading materials (Chowdhurry, 1963, Sang et al., 2002). Microorganisms form biofilms in these degrading materials, within these biofilms, some degrade the materials directly while others utilize the end products from the degradation of other microorganisms. They interact within the biofilms to degrade the materials and utilize the products of the degradation. Fungi have been shown by another study to possess the potential to degrade polymer in the soil (Sang et al., 2002). They do this by secreting diffusible enzymes, the secreted enzymes seems to have difficulty in travelling long distances from colonizing polymer degrading microorganisms, so that the traces molded by polymer degrading microorgamisms can be observed during their degradation process in soil. Therefore, the degradation rate is supposed to be determined by the area occupied by colonizing polymer degrading microorganisms. This is consistent with the result that the fast degradation rates by fungi were due to their fast surface growth rates.

This study has proven that paper bags are more liable to degrade faster than plastic bags and that environmental factor like salt water which represents the sea condition and sun has more effect on the biodegradability process of the suspended materials. It is therefore recommended to use more of paper bags for shopping and packaging of goods in our stalls.

\section{References}

[1]. Alien C. (2004) effects of ultraviolet light, temperature and relative humidity on the degradation of polulactic acid plastic films. Science, 55: 763-773.

[2]. American Public Health Association (1981). Standard methods for the examination of water and wastewater. $15^{\text {th }}$ edition. American Water Work Association and Water Pollution Control Federation. Ogden, Utah.

[3]. Athina O. And Reinart B (2012). Environmental effects on the biodegradability of pastic bags, paper bags and newspapers. Scribd.com

[4]. Barlaz M.A., Schaefer D.M., and Ham R.K. (1989). Bacterial population development and chemical characteristics of refuse decomposition in a simulated sanitary landfill. Applied Environmental Microbiology, 55(1): 55 - 65.

[5]. Chowdhury, A.A. (1963). Poly-b-hydroxybuttersa'ure'abbauende Baketerien and Exoenzym. Arch. Mikrobiol. 47: 167 200.

[6]. Day, T.A and Neale P. (2002). Effects of UV - B radiation on terrestrial and aquatic primary producers. Annual review of Ecology and systematic 33: $371-396$.

[7]. Fawole, M.O. and Osho, B.A. (1998). Laboratory Manual of Microbiology. Spectrum $\quad$ Books $\quad$ Limited. $\quad$ P. 77. .genus Amycolatopsis. Biotechnol Lett;21:901-5.

[8]. Jennings E. (2012). Natural factors that degrade paper. Ehow contributor, $1999-2012$.

[9]. Joel FR. (1995). Polymer Science \& Technology: Introduction To Polymer Science, Eds. 3, Prentice Hall PTR Inc, Upper Saddle River, New Jersey 07458. P4-9.

[10]. Julian P.B and Jason A.T. (2012). Effect of the different types of substrates on the biodegradability of some plastic bags. Investigatory project study mode.com

[11]. Mueller R.J. (2006). Biological degradation of synthetic polyesters - enzymes as potential catalysts for polyester recycling. Procedures in Biochemistry, 41:2124-8.

[12]. Olayan H.B., H.S. Hamid, and E.D. Owen, (1996). Photochemical and thermal cross-linking of Polymers . Journal of Macromolecules. Sci. Rev. Macromoi. Chem. Phys. 36:671-719

[13]. Pospisil J, Nespurek S. (1997) Highlights in chemistry and physics of polymer. Macromolecular Symposia 115(1): 143 - 163.

[14]. Priyanka N, Archana T (2011) Biodegradability of Polythene and Plastic by the Help of Microorganism: A Way for Brighter Future. Journal of Environmental and Analytical Toxicology 1:111. doi:10.4172/2161-0525.1000111

[15]. Sabir, I., (2002) Plastic Industry in Pakistan. http://www.jang.com.pk/thenews/

[16]. Sang BI, Hori K, Tanji Y, Unno H (2002). Analysis of microbial community in the degradation of poly(3-hydroxybutyrate-co-3hydroxyvalerate) in soil. Proceedings of the Fifth International Symposium on Environmental Biotechnology, Kyoto, Japan;. p. 981-4.

[17]. Scott G.( 1999) Polymers in modern life. Polymers and the Environment. Cambridge,

[18]. Seymour RB. (1989) Polymer Science Before \& After: Notable Developments During The Lifetime Of Maurtis Dekkar. J Macromol Sci Chem 26: 1023-1032.

[19]. Shah, A.A., Tomoaki E., Daisuki M., Satoshi K., Noboru S., Numbi, R.K Toshiaki N. (2011). Role of microorganisms in biodegradation of plastics, $\mathrm{Ph}$. D. thesis.

[20]. Xunchi, P. And Zhao W. (2005). The Effect of Dissolved Oxygen on 2000, China. Sichuan University Press, 2005 